\title{
SUSTAINABILITY OF CARDAMOM COMPARATIVE ADVANTAGE IN CENTRAL JAVA PROVINCE, INDONESIA
}

\author{
A Qonita, E W Riptanti, R Uchyani \\ Agribussiness Department, Faculty of Agriculture, Universitas Sebelas Maret, Surakarta \\ Corespondent Email : erlynawida@staff.uns.ac.id
}

\begin{abstract}
Cardamom is one of important spice commodities in the world; however, Indonesia's export contribution to global market is considered low. Cardamom production in Central Java contributes to the export of Indonesian cardamom. Central Java has the potential of human and natural resource for cardamom cultivation, but it has not been optimally utilized. This article aims to study the comparative advantages of cardamom and its sustainability. The design of this study is exploratory research, in which a research aims to obtain description or study on the condition of comparative advantage of cardamom in Central Java. Revealed Comparative Agency (RCA) belongs to one of methods used to find out competitiveness of commodity export of a country viewed from a comparative advantage. Cardamom sustainability is analyzed descriptively based on the actual situation and by using RCA result analysis. The result shows that the RCA value above 1 means in that period the cardamom commodity of Central Java has a strong comparative advantage in the international market. Despite the strong comparative advantage, its value tends to decrease. A serious concern should be given, considering the sharp decline. Therefore, the sustainability of cardamom comparative advantage needs to be improved.
\end{abstract}

Keywords: cardamom commodity, sustainability of cardamom, comparative advantage.

\section{INTRODUCTION}

A large number of people in developing countries have traditionally depended on products derived from plants, especially from forests, for curing human and livestock ailments. Additionally, several aromatic plants are popular for domestic and commercial uses. Collectively they are called medicinal and aromatic plants (MAPs). The growing demand for MAPs makes them remunerative alternative crops to the traditional ones for smallholders in the tropics [1]. One of the MAPs is cardamom.

Cardamom, the "Queen of Spices" is the third most expensive spices, next only to saffron and sometimes vanilla. It is of Indian origin and enjoyed a monopoly among spices being traded with Middle East, Greece and such ancient countries for some 3 millennia ago [2]. Cardamom is an important high value spice crop [3]. India and Saudi Arabia consume more than half of the world's total cardamom production. In Arab countries and India, cardamom is a common flavoring ingredient for coffee and tea. In Scandinavia, as well as in Germany and Russia, it is used to flavor cakes, pastries, and sausages. It is popular in Indian and South Asian cooking and used to make spice blends, such as curries and garam masala. In Eastern medicinal practices it is used for curing such ailments as influenza, infections, asthma, bronchitis, cardiac disorders, diarrhea, nausea, cataracts, and for strengthening the nervous system [4].

Cardamom has been a major agricultural cash crop and export commodity of Southeast Asian countries in recent years [5]. Indonesia holds a potential opportunity to be a 
pharmaceutical production country. On the other side, Indonesia faces agricultural product and market competition internationally and domestically [6]. Indonesia is one of the cardamom or "Javanese cardamom" producers in Southeast Asia, but its value has declined in the last 5 years. There are two kinds of cardamom in Indonesia, Javanese cardamom (Amomum compactum) and Indian cardamom (Elettaria cardamomum). Javanese cardamom (Amomum compactum) is often used as spices for certain food and for herb ingredient. Central Java, as one of the cardamom producers in Indonesia, shows the same result (see Table 1). The contribution of Central Java cardamom export value fluctuates due to cardamom production for domestic market (e.g.: herb industry / food industry).

Table 1. Cardamom Export Value in Central Java and Indonesia from 2012 - 2016 in USD

\begin{tabular}{ccrrrrr}
\hline HS & Region & \multicolumn{1}{c}{2012} & \multicolumn{1}{c}{2013} & \multicolumn{1}{c}{2014} & \multicolumn{1}{c}{2015} & \multicolumn{1}{c}{2016} \\
\hline 090830 & Central Java & $7,728,354$ & $3,676,129$ & $3,996,925$ & $4,386,658$ & $2,515,540$ \\
090830 & Indonesia & $16,977,378$ & $10,729,475$ & $10,145,154$ & $7,785,335$ & $6,202,939$ \\
$\begin{array}{l}\text { Percentage of Central Java } \\
\text { cardamom export value to }\end{array}$ & 45.52 & 34.26 & 39.40 & 56.35 & 40.55 \\
Indonesia. & & & & & \\
\hline
\end{tabular}

Source : [7].

Central Java cardamom production area lies on high lands / mountain, just as the other cardamom producer countries where cardamom uses marginal and sloppy lands in which other crops can't grow. Cardamom grows from humid subtropical belts at $400 \mathrm{~m}$ to warm temperate agro-climatic belts up to 2,300 m elevations (International Centre for Integrated Mountain Development [8]. Cardamom cultivating, harvesting, and processing are carried out in traditional ways with very little scientific influence [5].

World's cardamom demand is very high, yet lack of production is occurring in cardamom. Reasons for the decline include land degradation causing reduction in manure production, improper use of chemical fertilizers, use of old and nonviable seeds, and lack of irrigation facilities, especially in the hills with their difficult topography [9]. The cardamom plantation area tends to decrease every year (see Table 2).

Table 2. Cardamom Area and Production in Central Java and Indonesia from 2014-2016

\begin{tabular}{lcccccc}
\hline & \multicolumn{2}{c}{2014} & \multicolumn{2}{c}{2015} & \multicolumn{2}{c}{2016} \\
\cline { 2 - 7 } Annotation & $\begin{array}{c}\text { Area } \\
\text { (ha) }\end{array}$ & $\begin{array}{c}\text { Production } \\
\text { (ton) }\end{array}$ & $\begin{array}{c}\text { Area } \\
\text { (ha) }\end{array}$ & $\begin{array}{c}\text { Production } \\
\text { (ton) }\end{array}$ & $\begin{array}{c}\text { Area } \\
\text { (ha) }\end{array}$ & $\begin{array}{c}\text { Production } \\
\text { (ton) }\end{array}$ \\
\hline Central Java & 1,665 & 21,419 & 1,217 & 21,419 & 1,112 & 22,478 \\
Indonesia & 4,230 & 72,760 & 4,344 & 93,121 & 3,879 & 86,144 \\
\hline $\begin{array}{l}\text { Percentage } \\
\text { of Central }\end{array}$ & & & & & & \\
Java to & 39.35 & 29.44 & 28.03 & 23.00 & 28.67 & 26.09 \\
Indonesia & & & & & & \\
\hline
\end{tabular}

Data source : Statistics Indonesia [10] 
Not every district / city in Central Java produces cardamom, only those located on highlands or mountains can produce cardamom. Cardamom plantation area is less than those of the other plants such as vegetables, even though cardamom has higher selling price compared to the production and agro-climatological conformity.

Table 3. Highest Cardamom Area and Production in 10 Districts of Central Java from 2012 2016

$\begin{array}{lllll}2012 & 2013 & 2014 & 2015 & 2016\end{array}$

$\begin{array}{ccccccccccc}\text { No District } & \begin{array}{l}\text { area } \\ \text { (ha) }\end{array} & \begin{array}{c}\text { production } \\ \text { (ton) }\end{array} & \begin{array}{c}\text { area } \\ \text { (ha) }\end{array} & \begin{array}{c}\text { production } \\ \text { (ton) }\end{array} & \begin{array}{c}\text { area } \\ \text { (ha) }\end{array} & \begin{array}{c}\text { production } \\ \text { (ton) }\end{array} & \begin{array}{c}\text { area } \\ \text { (ha) }\end{array} & \begin{array}{c}\text { production } \\ \text { (ton) }\end{array} & \begin{array}{c}\text { area } \\ \text { (ha) }\end{array} & \begin{array}{c}\text { production } \\ \text { (ton) }\end{array}\end{array}$

\begin{tabular}{llrrrrrrrrrr}
\hline 1 & Banyumas & 79 & 850 & 41 & 521 & 61 & 2,233 & 115 & 2,233 & 139 & 2,035 \\
2 & Purbalingga & 183 & 1,457 & 174 & 1,584 & 178 & 1,201 & 173 & 1,201 & 68 & 641 \\
3 & Banjarnegara & 112 & 1,498 & 142 & 1,092 & 165 & 2,114 & 55 & 2,114 & 98 & 930 \\
4 & Purworejo & 22 & 310 & 208 & 2,071 & 116 & 769 & 10 & 769 & 38 & 893 \\
5 & Wonosobo & 100 & 2,448 & 159 & 2,471 & 139 & 1,786 & 74 & 1,786 & 158 & 4,110 \\
6 & Magelang & 104 & 2,165 & 271 & 3,006 & 274 & 4,860 & 226 & 4,860 & 165 & 6,813 \\
7 & Semarang & 157 & 1,389 & 145 & 1,403 & 211 & 2,333 & 200 & 2,333 & 166 & 2,668 \\
8 & Temanggung & 25 & 1,136 & 19 & 259 & 72 & 1,222 & 55 & 1,222 & 37 & 736 \\
9 & Kendal & 45 & 717 & 96 & 570 & 72 & 1,242 & 76 & 1,242 & 29 & 934 \\
10 & Tegal & 61 & 36 & 129 & 387 & 188 & 819 & 31 & 819 & 14 & 496 \\
\hline Central Java & 990 & 14,487 & 1,607 & 17,003 & 1,665 & 21,419 & 1,217 & 21,419 & 1,112 & 22,478 \\
\hline
\end{tabular}

Source : Statistics of Central Java [11-15]

Table 3 shows that there has been an increase of production in the last 5 years, despite the decline of plantation area. It means that the cardamom productivity increases. Farmers in the mountainous areas are less interested in cultivating cardamom due to the relatively first, long harvesting period, whereas they need to earn a living. The human and natural resources, if not properly managed, may bring negative impact to the sustainability of cardamom cultivation in Central Java. The domestic and global cardamom market is widely open, but it is useless without cardamom comparative advantage support. Therefore, this paper aims to study the cardamom comparative advantage and its sustainability.

\section{RESEARCH METHOD}

The Basic Method

The design of this study is exploratory research, in which a research aims to obtain description or study on the condition of cardamom comparative advantage in Central Java. Explanatory research seeks explanations to the observed phenomena, problems, or behaviors 
[16]. Cross-sectional approach was applied, in which a study is carried out only at a certain time without any treatment or action to object in order to portrait situation at a certain period.

\section{Types of Data, Sources of Data, and Data Collection}

Data include primary and secondary data. Primary data consist of the condition of comparative advantage seen from the aspects of agro-climatological conformity, cultivation, institution and management, and the sustainability. The data were obtained from in-depth interview with cardamom farmers, related institution, and collector merchants. Furthermore, the data were also obtained by observing the cardamom cultivation. Meanwhile, secondary data were gathered from Central Bureau of Statistics, Department of Industry and Trade, United Nations Commodity Trade and other relevant institutions.

\section{Location Determination Method}

Research location of Central Java was selected using purposive sampling under some considerations that are one of provinces producing cardamom and its region has a potential to develop, and it contributes to the export of cardamom.

\section{Data Analysis}

Revealed Comparative Advantage (RCA) Method

RCA method belongs to one of methods used to find out competitiveness of commodity export of a country or industry viewed from a comparative advantage [17]. The value of RCA systematically used in the research was resulted from the following formula:

$$
\operatorname{RCA}=\frac{X_{i j} / X_{t}}{W_{i j} / W_{t}}
$$

where RCA represents competitiveness of cardamom commodity export of Central Java viewed from comparative advantage, $\mathrm{X} i j$ denotes value of cardamom commodity export of Central Java province, $\mathrm{Xt}$ is total value of export of Central Java, W $i j$ is value of cardamom commodity export, and $\mathrm{Wt}$ is total value of export of Indonesia. The value of competitiveness resulted from the computation entails two possibilities: either the value of RCA $>1$ which indicates that cardamom commodity export of Central Java has strong competitiveness or the value of $\mathrm{RCA}<1$, which reveals that cardamom commodity export of Central Java has weak competitiveness. The index of RCA shows the comparison between the current year value of RCA and the previous year value of RCA. The cardamom sustainability was analyzed descriptively based on the actual situation and by using RCA result analysis. Activities in qualitative data analysis were performed in interactive and continuous manners until they finished reaching data saturation. Activities of data analysis include data reduction, data display, and conclusion drawing/ verification [18].

\section{RESULTS AND DISCUSSION}

\section{A. Cardamom Comparative Advantage}

Based on a source, medicinal plants traded in Indonesia can be distinguished into medicinal plant cultivation and medicinal plants exploited directly from the forest. Currently, 
cultivated crops are only $22 \%$ and the direct forest harvesting is $78 \%$ [19]. These numbers include cardamom in Central Java. Taking cardamom from the forest requires relatively low production cost compared to the cost of when cultivating it. Cardamom in Central Java is partly non-intensively cultivated and mostly taken from the forest.

Cardamom comparative advantage means having an advantage in producing cardamom due to its efficient production cost. The measure of comparative advantage is carried out using Revealed Comparative Advantage (RCA). RCA in this study is defined as the export commodity cardamom in total of export commodity in Central Java is greater than the market of commodity export cardamom in total commodity exports in Indonesia. This condition makes Central Java to have a comparative advantage in producing specialized cardamom commodities based on the efficiency compared to other countries (see Table 4). Although it has a very large comparative advantage but its value shows a decreasing tendency. This needs serious attention since the sharp decline happened. In the long term, the sustainability of this comparative advantage needs to be maintained and enhanced.

Table 4. Cardamom RCA Analysis in 2012-2016

\begin{tabular}{lcc}
\hline Year & RCA Value of Cardamom \\
\hline 2012 & 19.38 \\
2013 & 11.74 \\
2014 & 12.31 \\
2015 & 15.75 \\
2016 & 10.93 \\
\hline Average & & 14.02
\end{tabular}

Source: Secondary data analysis (2018)

The RCA value above 1 means that within this period, cardamom commodity in Central Java has a strong comparative advantage in global market. Currently, cardamom is exported to Korea and the Netherlands. The value of comparative advantage of cardamom export of Central Java is also highly dependent on changes in the Rupiah exchange rate against the US dollar. This is because the value of the existing RCA is influenced by the value of exports calculated in US Dollars, thus the strengthening or weakening of the ID Rupiah against the US Dollar is very important in affecting the competitiveness of cardamom commodity in Central Java.

\section{B. Sustainability of Comparative Advantages}

Cardamom has a high comparative advantage but the cultivation to the marketing of cardamom experiences obstacles and this causes it to be considered less pre-eminent commodity to be cultivated en masse. Several things recorded from the results of this study are 1) the cultivation of cardamom has not been well managed, 2) the process of postharvesting to the packaging is not in accordance with the standard operating procedures, and 3) farmers still apply traditional marketing. On the other hand, cardamom is a "Queen of Spices" in the global market but the contribution of the export market in Indonesia is still low. Therefore, to increase the cardamom market in the global market, it needs to be supported by the farming sector management so that comparative advantage can increase and 
becomes sustainable. A review of the sustainability of comparative advantages is discussed based on the agro-climatological suitability, cultivation techniques, and cooperation with stakeholders.

\section{Agro-climatological suitability}

Cardamom grows wild in the Southeast Asian uplands, specifically in the mountain rainforests. It requires a moist and shady environment. The most favorable conditions include a mean yearly temperature ranging from 19 to $22^{\circ} \mathrm{C}$, with over $12^{\circ} \mathrm{C}$ in the coldest months, and yearly rainfall between 1,200 and 2,400 $\mathrm{mm}[20,8]$. Cardamom is a climate sensitive grown plant as rain fed tropical understory crop in cardamom hills since 19th century [21]. Climate and weather variation can substantially influence the development and distribution of pest insects and disease causing organisms across cardamom agroecosystems [22]. Cardamom is a shade loving plant and grows well within $50 \%$ to $60 \%$ shade conditions. It grows well in areas with well-distributed rainfall spread around 250 days per year. The general decrease in precipitation level especially for the monsoon months can affect cardamom productivity as it is sensitive both to drought and excess rainfall. Good irrigation can be done with the use of sprinkle. Managing cardamom ecosystem, especially forest and water quality protection and profitable cardamom farming could be the major future challenges [23]. The development area of cardamom in Central Java is based on the agro-climatological conditions, which are Banyumas, Purbalingga, Banjarnegara, Purworejo, Wonosobo, Magelang, Semarang, Temanggung, Kendal and Tegal. The land used can be from PERHUTANI with agroforestry system [24], and tegal or yard of the population according to conditions. These are composites in response to socioeconomic conditions [24].

The crop can be integrated into the secondary forest formations dominant without any ecological damage. Planted under forest canopy, it enables the conservation and development of a wooded stratum, a guarantee for the subsistence of forest environmental conditions (ecological diversity, soil structure and fertility, moisture, microclimate, etc.). The first fruit appears three years after planting, but the main harvest begins after the fifth year. It continues increasing until the 10th year, and then the plot wears out slowly over a 10 -year period. Rational management entails replanting around the 15th year to regenerate the plantation [25]. Therefore, replantation of cardamom and phase wise agroforestry rotation after 20 years could be an ecologically and economically sustainable management practice [26].

2. Cultivation techniques

Cardamom agroforestry is a mountain adaptive slope land management and production system that helps conserving soil and water, maintain soil fertility and high rate of carbon sequestration than other land use system in the region. The system is a major contributor of sustainable development in the mountain region by providing socio ecological sustainability, watershed functions and cultural [5].

Sustainable agricultural intensification (SAI) would improve long-term productivity and reduce pressure on forest reserves [27]. Developing sustainable value chains that support higher agricultural productivity and are enable to improve 
environmental, economic, and social outcomes are imperative. Poor extension has been identified as a key constraint to increase household production and income [28]. The government gives a counseling and training of cultivation techniques, and both harvesting and post-harvesting processes in improving the farmers' and the group of cardamom farmers' knowledge and skill. Social capital formation through the promotion of extension services and technological advice would raise awareness of management practices that improve fertility and subsequently shift the labor-led intensification strategies towards more sustainable and longer term productive land uses [27,29]. To promote cardamom revival, policies have to be framed that focus strictly on preventing or combating disease [30].

The optimal production of medicinal plants as herbs raw material is determined by some factors, including cultivation environment, cultivation techniques, as well as a means of production. The former includes such requirements for growth as climate, growing media, and elevation. Meanwhile, the middle and the latter involve seed varieties used, seed preparation and nursery, land cultivation, planting, care, and harvesting (the Standard Operating Procedure issued by Indonesian Spices and Medicinal Crops Research Institute (Balai Penelitian Tanaman Rempah dan Obat) (2004) [6]. This can be occurred for cardamom cultivation.

Cardamom growing countries are implementing various policies to improve the crops. Most such policies seem to emphasize replanting, rejuvenation, and crop maintenance. However, positive interventions are also being undertaken in the area of postharvest processing and marketing [31]. In Central Java, replanting is very important for improving the productivity particularly non-cultivated cardamom. The crop can be integrated into the secondary forest formations dominant without any ecological damage. Planted under forest canopy, it enables the conservation and development of a wooded stratum, a guarantee for the subsistence of forest environmental conditions (ecological diversity, soil structure and fertility, moisture, microclimate, etc.).

All this time, there are no farmers or producers producing a good quality of cardamom seeds. Therefore, cardamom-breeding programs should be made and aimed to produce new F1 hybrids for sustainability. F1 cardamom hybrids do not only have high yield potential and overall plant performance but can also increase productivity on account of their mosaic resistance. Therefore, yield, yield components, quality, resistance, and overall plant performance can be effectively improved in cardamom [3].

Organic cardamom can be profitably grown in home gardens. By implementing agro forestry systems, the harmful impact of cardamom cultivation on the forests might be dramatically reduced [32]. The promotion of organic cardamom cultivation would additionally raise the value of the product on the market by up to $30-40 \%$. Certification of organic products has already started in some villages. A one-hectare produces from 20 to $750 \mathrm{~kg}$ of dried fruit depending on its age [8].

3. Cooperation with stakeholders 
The response of farmers in cultivating cardamom depends on the certainty of the selling price, quantity and quality. The improvement of product quality can be done by establishing cooperation between farmer (or group of farmers) and herbal medicine company or traditional medicine. Farmers in mountainous areas of Central Java on average have relatively narrow land, whereas most of the existing land is state-owned forest and the land is suited for cardamom plants. Therefore, the extensification and intensification of cardamom cultivation is by involving PERUM PERHUTANI and the office of Forestry and Estate Crops in suing state-owned production forest. Joint forest management with farmers and contract farming with drug companies with buyback arrangement will promote cultivation of medicinal plants [1].

A mutually cooperation between farmers and herbal medicine/traditional medicine companies will have a positive impact on other farmers' response in cultivating cardamom. In general, farmers will cultivate if they have seen evidence of a positive effect on the increase in household income. The contract between farmers and herbal medicine or traditional medicine companies will encourage the cardamom farmers in the development of cultivation.

\section{CONCLUSION}

Cardamom in Central Java is produced from the non-intensively cultivation and mostly taken from the forest. However, cardamom has a comparative advantage because of its natural resource that fits with the terms of growth. This comparative advantage shows a very sharp decline trend, so that in the long term, the sustainability of this comparative advantage needs to be maintained and enhanced. A review of the sustainability of comparative advantages is observed in terms of agro-climatological suitability, cultivation techniques, and cooperation with stakeholders.

\section{Acknowledgements}

We would like to express our sincere gratitude to Universitas Sebelas Maret for funding this research. Our sincere appreciation also extended to all parties who have provided information to complete this article.

\section{REFERENCES}

1. Rao, M.R.; Palada, M.C.; Becker, B.N. Medicinal and aromatic plants in agroforestry systems. Agroforestry Systems. 2004, 61, 107-122.

2. George, M. ; Cherian, E. Emergent global marketing challenges for kerala cardamom producers vis-à-vis role of the spice board of India. International Journal of Community Development \& Management Studies. 2017, 1, $39-62$.

3. Prasath, D.; Venugopal, M. N.; Senthilkumar, R.; Leela, N. K. Hybrid performance for yield and yield components in cardamom (Elettaria cardamom Maton). Euphytica. 2009. 168, 49-60.

4. Ravindran, P.N.; Madhusoodanan, K.J. editors. Cardamom: The genus elettaria. medicinal and aromatic plants - industrial profiles. United Kingdom: Taylor and Francis. London. 2002. 
5. Sharma, G.; Sharma, R.; Sharma, E. Traditional knowledge systems in large cardamom farming: biophysical and management diversity in Indian mountainous regions. Indian Journal of Traditional Knowledge. 2009. 8, 17 - 22.

6. Riptanti, E. W.; Qonita, R. A.; Fajarningsih, R. U. The competitiveness of medicinal plants in Central Java Indonesia. ICSAE. IOP Conf. Series: Earth and Environmental Science 142, 012018. 2018.

7. Dinas Perindustrian dan Perdagangan Jawa Tengah. Realisasi Ekspor - Impor Jawa Tengah Periode 2012 -2017 (Oktober). Bidang Perdagangan Luar Negeri. Dinas Perindustrian dan Perdagangan Jawa Tengah. Indonesia. 2017.

8. International Centre for Integrated Mountain Development (ICIMOD). Climate-Resilient Practices for Sustainability of Large Cardamom Production Systems in Nepal. The Mountain Institute India. 2017.

9. Govind, K. C.; Karki, T. B.; Shrestha, J.; Achhami, B. B. Status and prospects of maize research in Nepal. Journal of Maize Research and Development. 2015, 1, 1-9.

10. BPS Statistics Indonesia. Statistical Yearbook of Indonesia 2017. BPS-Statistics Indonesia. Jakarta. Indonesia. 2017.

11. BPS Statistics of Jawa Tengah Province. Jawa Tengah Province in Figures 2013. BPS Statistics of Jawa Tengah Province. Indonesia. 2013.

12. BPS Statistics of Jawa Tengah Province. Jawa Tengah Province in Figures 2014. BPS Statistics of Jawa Tengah Province. Indonesia. 2014.

13. BPS Statistics of Jawa Tengah Province. Jawa Tengah Province in Figures 2015. BPS Statistics of Jawa Tengah Province. Indonesia. 2015.

14. BPS Statistics of Jawa Tengah Province. Jawa Tengah Province in Figures 2016. BPS Statistics of Jawa Tengah Province. Indonesia. 2016.

15. BPS Statistics of Jawa Tengah Province. Jawa Tengah Province in Figures 2017. BPS Statistics of Jawa Tengah Province. Indonesia. 2017.

16. Nueuman, W. L. Social research methods: qualitative and quantitative approach. Allyn and Bacon. 1994.

17. Balassa, B. A. Trade liberalization and revealed comparative advantage. Manchester School of Economic Studies. 1965, 32 (2), 99-122.

18. Muhammad, A. Farmers community empowerment through institutional strengthening of rural food barn. Int. Jour. of Agr.e Sys. 2016, 4, 161-167.

19. Ernawati, M. Editor Zamroni Salim dan Ernawati Munadi. Info Komoditi Tanaman Obat. Badan Pengkajian dan Pengembangan Perdagangan Kementerian Perdagangan Republik Indonesia. 2017.

20. Olivier, D.; Phoui, V.; Julien, R. Introducing cash crops in shifting cultivation regions the experience with cardamom in Laos. Agroforestry Systems. 2006, 66, 65-76.

21. Murugan, M.; Backiyarani, S.; Josephrajkumar, A.; Hiremath, M.B.; Shetty, P.K. Yield of small cardamom (Elettaria cardamomum M) variety PV1 as influenced by levels of nutrients and neem cake under rain fed condition in Southern Western Ghats, India. Caspian J Environ Sci. 2007, 5 (2), 19-25.

22. Murugan, M.; Shetty, P. K.; Ravi, R.; Anandhi, A.; Rajkumar, A.J. Climate change and crop yields in the Indian Cardamom Hills, 1978-2007 CE. Climatic Change. 2012, 110, 737-753.

23. Murugan, P. K.; Shetty, A.; Anandhi.; Ravi, R. Present and future climate change in Indian Cardamom Hills: Implications for cardamom production and sustainability. British Journal of Environment \& Climate Change. 2012, 2 (4), 368-390.

24. Wiersum, K. F. Forest gardens as an 'intermediate' land-use system in the nature-culture continuum: characteristics and future potential. Agroforestry Systems. 2004, 61, $123-$ 134. 
25. Sharma,G.; Sharma, R.; Sharma, E.; Influence of stand age on nutrient and energy release through decomposition in alder-cardamom agroforestry systems of the Eastern Himalayas. Ecol Res. 2008, 23, 99-106.

26. Sharma, G.; Sharma, R.; Sharma, E. Impact of altitudinal gradients on energetics and efficiencies of N2-fixation in alder-cardamom agroforestry systems of the Eastern Himalayas. Ecol Res. 2010, 25, 1-12.

27. Renee, B.; Dagmar, M.; Heini, V. Sustainable agricultural intensification: the role of cardamom agroforestry in the East Usambaras, Tanzania. International Journal of Agricultural Sustainability. 2012, September, $1-21$.

28. Reyes, T.; Quiroz, R.; Msikula, S. Socio-economic comparison between traditional and improved cultivation methods in agroforestry systems, East Usambara Mountains, Tanzania. Environmental Management. 2005, 36 (5), 682-690.

29. Bhattarai, N. K.; Deka, T. N.; Chhetri, P.; Harsha, K. N.; Gupta, U. Livelihood Improvement through Sustainable Large Cardamom Cultivation in North Sikkim. International Journal of Scientific and Research Publications. 2013, Volume 3, Issue 5, $1-4$

30. Sony, K. C.; Bishnu, R. U. The political economy of cardamom farming in Eastern Nepal: Crop disease, coping strategies, and institutional innovation. SAGE Journal. 2017, April-June, 1 -15.

31. Angom, I. S.; Anand, K.P. Postharvest processing of large cardamom in the Eastern Himalaya. Mountain Research and Development. 2013, 33 (4), 453-462.

32. Teija, R.; Olavi, L.; Quiroz, R. Small cardamom-precious for people, harmful for mountain forests. Mountain Research and Development. 2006, 26 (2), 131-137. 